\title{
Enterolithiasis in posterior urethral diverticulum: an uncommon complication following surgery for anorectal malformation
}

\author{
Devendra Kumar Yadav, ${ }^{1}$ Kashish Khanna, ${ }^{1}$ Vikram Khanna, ${ }^{2}$ Deepak Bagga ${ }^{3}$
}

${ }^{1}$ Pediatric Surgery, All India Institute of Medical Sciences, New Delhi, Delhi, India ${ }^{2}$ Pediatric Surgery, Lady Hardinge Medical College, New Delhi, Delhi, India

${ }^{3}$ Pediatric Surgery, Vardhman Mahavir Medical College and Safdarjung Hospital, New Delhi, Delhi, India

Correspondence to Dr Kashish Khanna, kash.modern@gmail.com

Accepted 22 August 2018

\section{DESCRIPTION}

A posterior urethral diverticulum (PUD) may be formed when a part of the terminal rectal stump is left attached to the posterior urethra during fistula ligation in surgery for anorectal malformation (ARM).

A 13-year-old boy presented with the complaints of burning micturition, postvoid dribbling and vague pain in the left lower abdomen for the last 4 months. The child had high ARM and underwent all three stages of surgery (colostomy, transabdominal pullthrough procedure and colostomy closure) elsewhere. On evaluation, the plain X-ray pelvis showed huge, multiple radio-opaque shadows in the region of the bladder (figure 1A). On an ultrasound, these acoustic shadows caused by the stones appeared to be posterior to the bladder and could not be appreciated well in full bladder state. A CT scan further confirmed these radio-opaque shadows to be posterior, but not within the urinary bladder and anterior to the rectum (figure $1 \mathrm{~B}$ ). This raised the suspicion of stones in a PUD.

On pelvic exploration, there were multiple huge stones found in a $5 \times 6 \mathrm{~cm}$ rectal mucosal lined cavity. This was located posterior to the bladder but anterior to the rectum and was communicating with the bladder through a fistulous tract. The fistulous tract and the attached dilated rectal stump were excised, and all the stones were removed. There were no signs of urinary or bowel complaints until 6 months of follow-up.

The PUD may be found in $17.8 \%$ of the patients after surgery for ARM and is more common in patients with recto-urethral bulbar fistula who have been repaired transabdominally or by the laparoscopically assisted anorectal pull-through (LAARP) procedure. ${ }^{1}$ These patients may be asymptomatic for the initial few years but may later on present with the passage of mucus through urethra, recurrent urinary tract infections, epididymo-orchitis, dribbling and rarely stone formation. ${ }^{1}$ It is hypothesised that the mixing of urine with the mucus may alter the $\mathrm{pH}$ of the fistulous region resulting in an environment conducive for enterolith formation. These enteroliths may keep expanding layer by layer in the residual rectal stump and result in enlargement of the diverticulum as seen in our case. Such patients may even present with compressive symptoms like constipation when the enlarged diverticula compresses the rectum or with incomplete micturition, postvoid dribbling, significant postvoid residue and urinary tract infections if it compresses the bladder outlet. The PUD containing fluid, mucus or debris and the surrounding structures (urinary bladder, ureters, rectum and neurovascular structures) can be visualised best by MRI. ${ }^{2}$ The treatment consists of reoperation through the posterior sagittal approach by mobilising the rectum and then visualising the urinary tract from behind. The diverticulum can be opened and the entire area excised under vision, followed by the repair of the urinary tract. However, in the era of LAARP, Lopez et $a l^{3}$ have suggested active 


\section{Learning points}

In patients with high anorectal malformation with rectourethral fistula, the fistula should be ligated as close to the urinary tract as possible to prevent the formation of a posterior urethral diverticulum.

- Posterior urethral diverticulum may present with passage of mucus through urethra, repeated urinary tract infections, epididymo-orchitis and rarely with complications like enterolithiasis.

surveillance and a long follow-up in asymptomatic patients of PUD.
Contributors The child was managed under the care of DKY and DB. The manuscript was drafted by KK. The data were collected by VK and DKY. The final draft was read and finalised by all authors before submission. The revised manuscript has been read by all authors.

Funding The authors have not declared a specific grant for this research from any funding agency in the public, commercial or not-for-profit sectors.

Competing interests None declared.

Patient consent Obtained.

Provenance and peer review Not commissioned; externally peer reviewed.

\section{REFERENCES}

1 Alam S, Lawal TA, Peña A, et al. Acquired posterior urethral diverticulum following surgery for anorectal malformations. J Pediatr Surg 2011;46:1231-5.

2 Eltomey MA, Donnelly LF, Emery KH, et al. Postoperative pelvic MRI of anorectal malformations. AJR Am J Roentgenol 2008;191:1469-76.

3 López PJ, Guelfand M, Angel L, et al. Urethral diverticulum after laparoscopicallyassisted anorectal pull-through (LAARP) for anorectal malformation: is resection of the diverticulum always necessary? Arch Esp Urol 2010;63:297-301.

Copyright 2018 BMJ Publishing Group. All rights reserved. For permission to reuse any of this content visit http://group.bmj.com/group/rights-licensing/permissions.

BMJ Case Report Fellows may re-use this article for personal use and teaching without any further permission.

Become a Fellow of BMJ Case Reports today and you can:

- Submit as many cases as you like

- Enjoy fast sympathetic peer review and rapid publication of accepted articles

- Access all the published articles

- Re-use any of the published material for personal use and teaching without further permission

For information on Institutional Fellowships contact consortiasales@bmjgroup.com

Visit casereports.bmj.com for more articles like this and to become a Fellow 